\title{
IMMUNE RESPONSE OF THE HARDERIAN GLAND IN CHICKENS TO INFECTIOUS BRONCHITIS CORONAVIRUS
}

\author{
S. V. Guralska ${ }^{1}$, T. F. Kot ${ }^{1}$, N. V. Dyshliuk ${ }^{2}$, S. S. Zaika ${ }^{1}$, Z. V. Khomenko ${ }^{1}$ \\ ${ }^{1}$ Polissia National University \\ 7, Stary Boulevard, Zhytomyr, Ukraine, 10008 \\ ${ }^{2}$ National University of Life and Environmental Sciences of Ukraine \\ 15, Heroyiv Oborony Str, Kyiv, Ukraine, 03041
}

E-mail: guralska@ukr.net",tkotvet@ukr.net,dushlyuk@ukr.net,lana_zaika@ukr.net,zorianakhomenko@ukr.net

Received October 27, 2020 / Received March 03, 2021 / Accepted March 19, 2021

\begin{abstract}
Aim. To determine the difference in immune responses of the harderian gland in clinically healthy chickens and the ones with infectious bronchitis based on the content, localization and morphometric estimation of the surface markers of T- and B-lymphocytes and to determine the differentiation index as an indicator of assessing body defenses. Methods. Histological, immunohistochemical, optical, morphometric and statistical. Results. The histological study of the harderian gland of chickens with infectious bronchitis determined the swelling and proliferation of the connective tissue as well as infiltration of secretory lobules by lymphoid cells. It was found that the immunity of chickens with infectious bronchitis, in which the harderian gland plays a relevant role, depends considerably on the differentiation index of immunocompetent cells. There was a reliable 1.77- and 1.36-fold decrease in this indicator for 40- and 90-day-old chickens, respectively, in case of nephroso-nephritic form of infectious bronchitis which demonstrated a weaker function of the defense cells of this organ. According to the cytomorphometric analysis, the number of cells, expressing $\mathrm{CD}^{+}, \mathrm{CD}^{+}, \mathrm{CD} 20^{+}, \mathrm{CD}_{4} 5 \mathrm{RA}^{+}$markers in the harderian gland of sick 20-, 40-, and 90-day-old chickens with respiratory and nephroso-nephritic forms of infectious bronchitis was reliably $(\mathrm{P}<0.05)$ increasing compared to the clinically healthy chickens. For instance, the number of mature B-lymphocytes increased in sick 20-day-old chickens -2.44 times, 40-day-old chickens -1.88 times, and 90-day-old ones -2.62 times compared to clinically healthy chickens. Conclusions. The data were obtained about the changes in quantitative and qualitative composition of lymphocytes with surface markers $\mathrm{CD} 4^{+}, \mathrm{CD} 8^{+}, \mathrm{CD} 20^{+}, \mathrm{CD}_{4} \mathrm{RA}^{+}$in the harderian gland of chickens with infectious bronchitis. Our results will supplement current knowledge about the feasibility of immunohistochemical methods in the diagnostics of avian infectious bronchitis.
\end{abstract}

Key words: B-lymphocytes, humoral immunity, immunosuppression, avian infectious bronchitis, naive T-helpers, natural T-helpers, T-cytotoxic cells, foreign antigen.

DOI: https://doi.org/10.15407/agrisp8.01.058

\section{INTRODUCTION}

Avian infectious bronchitis (AIB) is diagnosed practically in all the countries with developed poultry breeding (Cook J et al, 2012, Jackwood M, 2012), causing considerable damage both for private households and breeding farms. The economic loss includes death of young birds, decreased egg and meat productivity, and thus lower quality of eggs and meat of the poultry that has recovered, and higher expenses for prevention and elimination of this disease (Cavanagh D, 2007, Ban-

(C) S. V. GURALSKA, T. F. KOT, N. V. DYSHLIUK, S. S. ZAIKA, Z. V. KHOMENKO, 2021 de $\mathrm{F}$ et al, 2015, Valastro $\mathrm{V}$ et al, 2016). The use of live and inactivated vaccines takes the main place in preventing and eliminating AIB (Cook J et al, 2012, Bru $\mathrm{T}$ et al, 2017). However, the success of vaccination is incomplete due to constant occurrence of different antigen variants (Ignjatovic J, Sapats S, 2000), high level of mutation and short generation time (Khadija $\mathrm{K}$ et al, 2016). Thus, it is hard to control the AIB virus using vaccination; the fight with this disease requires searching for new methods (Smith J et al, 2015).

Avian infectious bronchitis virus (RNA-genome virus from Coronaviridae family, Coronavirus genus) affects the organs of breathing, excretion, and reproduc- 
tion (Jackwood M, 2012). Therefore, the respiratory, nephroso-nephrite and reproductive forms of this disease are distinguished (Sarah E et al, 2014, Bru T et al, 2017, Guralska S et al, 2019, Karimi V et al, 2019). The intestinal form is also detected (Dhinakar Raj G, Jones RC, 1997, Balestrin E et al, 2014). In addition, the disease has muscular and immunosuppressive manifestations (Najimudeen S et al, 2020). Chickens of different age are susceptible to the infectious bronchitis virus. However, they are most vulnerable at the age of 30 days and prior to laying eggs (Alazawy A et al, 2017, Habibi M et al, 2017).

Deeper understanding of the pathogenesis of avian infectious bronchitis requires the morphological study of the immune defense organs, and the main role in developing immune reactions is played by the harderian gland (Bande F et al, 2017, Zegpi R et al, 2019).

It is believed that the harderian gland participates in different functions, including moisturizing, cleansing, and defense, and it also is a source of pheromones (Khan M et al, 2007, Frahmand S, Mohammadpour A, 2015, Klecowska-Nawrot J et al, 2015). The immune response takes a relevant place among the functions, fulfilled by the harderian gland (Jahan M et al, 2018). Along with the cloacal sac, spleen and caecal glands, the harderian gland forms the peripheral system of immune defense organs and participates in both general and local immunity (Jahan M et al, 2006, 2018, Khan $M$ et al, 2007).

This study is a continuation of a cycle of investigations, dedicated to the pathomorphology and preventive vaccination of avian infectious bronchitis. For instance, previously we have conducted the studies on the impact of AIB virus on the organs of hemopoiesis and immunogenesis (Guralska S, 2017), pathomorphological changes in parenchymatous organs of chickens under different forms of disease manifestation (Guralska S et al, 2019); the impact of vaccination on the morphology and immunohistochemistry of the harderian gland in chickens (Guralska S et al, 2020) and the application of the immunomodulator under vaccination on the morphology of the harderian gland (Guralska S, Budnik T, 2020).

The aim of our work was to investigate the morphofunctional condition of the harderian gland in chickens under infectious bronchitis. For this purpose, we determined immunohistochemical indices (the number and specificities of the behavioral character of stained cells, the differentiation index) of the organ in clinically healthy chickens and the ones with avian infectious bronchitis.

\section{MATERIALS AND METHODS}

The harderian gland was isolated for the study from 36 clinically healthy and spontaneously sick chickens (20, 40, and 90-day-old) at the Solotvynska Ptakhofabryka branch of Zelenyy Val LLC in the village of Staryi Solotvyn, Berdychiv district, Zhytomyr region, Ukraine. The diagnosis of avian infectious bronchitis was set in a holistic way (with the consideration of epizootological and clinical data, pathological-anatomical changes, and the results of enzyme-linked immunosorbent assay).

The study of the condition of the harderian gland in chickens with infectious bronchitis was conducted by determining and analyzing the immunohistochemical indices: determining the number of T-helpers $\left(\mathrm{CD}^{+}\right)$, T-cytotoxic cells $\left(\mathrm{CD} 8^{+}\right)$, naive $\mathrm{T}$-helpers,

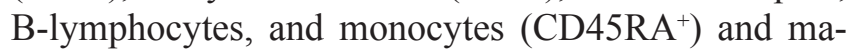
ture B-lymphocytes $\left(\mathrm{CD} 20^{+}\right)$, their location and differentiation index.

The harderian gland of chickens was fixed in $10 \%$ solution of buffered neutral formalin (Shandon Fixx, USA) for $24 \mathrm{~h}$ for the purposes of the histological and immunohistochemical investigation. After the dehydration, the investigated material was poured into paraffin with polymer additives (Richard-Allan Scientific, USA). The tissue sections of $5 \mu \mathrm{m}$ were made from paraffin blocks on the rotary microtome Microm HM325 (Carl Zeiss, Germany), placed on specimen slides (Menzel, Germany) and stained by standard methods using hematoxylin and oesin, and according to Van Gieson's staining (Kaltek, Italy). For further immunohistochemical investigations, some paraffin sections were placed on adhesive-covered slides of Super Frost Plus (Menzel, Germany).

The method of thermal treatment of sections in Target Retrieval Solution High pH buffer (DAKO, Denmark) was used after deparaffinization and rehydration for tissue antigen retrieval via processing in PT Modul (DAKO, Denmark) for $32 \mathrm{~min}$ at $98-99{ }^{\circ} \mathrm{C}$. Primary antibodies were applied after blocking endogenous peroxidase activity with the peroxidase block (Diagnostic Biosystems, USA) and after blocking non-specific binding of proteins using the protein block (Diagnostic Biosystems, USA). The immunohistochemical preparations were additionally stained with hemalum for 1-3 min (DAKO, Denmark) with subsequent placement of the stained sections into the Eukitt medium (Germany).

The study and microphotography of the histological preparations was conducted using the digital camera, installed into Primo Star microscope (Carl Zeiss, 
Germany) and connected to the personal computer. The placement and number of lymphocyte subpopulations were determined (per conditional unit of area at the magnification of $\times 400$ ). The quality indices of the marker expression were studied on the histological sections in 10 randomly selected fields of Primo Star microscope vision (Carl Zeiss, Germany) at the magnification of $\times 100, \times 400$.

The statistical processing of the obtained results was conducted by variation statistics methods using the personal computer and Statistica 6.0 program (StatSoft Inc., USA). The analysis of the obtained data was based on the indices of descriptive statistics, namely, the arithmetic mean, standard error of the mean value. The reliability of the obtained data was estimated using Fisher's F-criterion. The difference between two values was considered reliable at $\mathrm{P}<0.05$.

\section{RESULTS}

The histological study of the harderian gland of sick 20-day-old chickens determined the thickening of the capsule with the signs of swollen interlobular connective tissue and its infiltration by lymphoid cells (Fig. 1,a). The vessels of the harderian gland in such chickens were overfilled with blood and had increased permeability, which caused the swelling of the connective tissue. The epithelium of the glandular part of the harderian gland had expressed structure and was evenly stained.

The microscopic studies of the harderian gland of sick 40-day-old chickens demonstrated the impairments of its histoarchitecture which was manifested in expressed infiltration of the subcapsular zone and the secretory lobules by the lymphoid cells and the proliferation of the connective tissue. The epithelium of the secretory tubules of the gland was well-developed and the ducts contained a considerable amount of secretions (Fig. 1, b). The lymphoid accumulations were considerably larger compared to clinically healthy chickens, and single lymphoid nodules were located in the secretory part of the harderian gland.

A considerable amount of lymphoid tissue evolves in the form of lymphoid nodules in the harderian gland with the development of the organism. T-lymphocytes (cells with $\mathrm{CD}^{+}$markers) ensure cell-mediated forms of protecting the gland, and the character of their localization has its differences depending on the age of sick chickens and the development of the infectious process. The immunohistochemical studies have proven the presence of natural T-helpers in sick 20-day-old chickens with a respiratory form of AIB, which have not been found in clinically healthy chickens. Single lymphocytes with $\mathrm{CD}^{+}$in groups of several cells have been observed in the secretory part of the gland in sick 20-day-old chickens.

Natural T-helpers were also in the interlobular connective tissue of sick 40-day-old chickens. At the same time, these cells were located near the evolved lymphoid nodules in the form of insignificant accumulations. A considerable amount of lymphocytes with $\mathrm{CD}^{+}$markers was located in the secretory part of the harderian gland of 90-day-old chickens (Fig. 2,a).

The number of cells (at the magnification of 400), expressing $\mathrm{CD}^{+}{ }^{+}$marker according to the cytomorphometric analysis in sick 20, 40 and 90-day-old chickens with respiratory and nephroso-nephrite forms of AIB, was reliably $(\mathrm{P}<0.05)$ increasing compared to clinically healthy chickens: $2.36,2.77$ and 3.39 times respectively (Table).

The immunohistochemical studies determined the presence of lymphocytes with $\mathrm{CD}^{+}$markers in the harderian gland of sick 20-day-old chickens with a respiratory form of AIB, which were not found in clinically healthy chickens. These cells were found in the secretory lobules and around the lymphoid nodules in the harderian gland of sick 20,40, and 90-day-old chickens with infectious bronchitis (Fig. 2, b). The detailed analysis of immunohistochemical indices demonstrated that sick chickens had a considerable amount of T-helpers and T-cytotoxic cells, which formed a low $\mathrm{CD}^{+} / \mathrm{CD}^{+}$ratio. The differentiation index in sick 40 and 90-day-old chickens reliably $(\mathrm{P}<0.05)$ decreased 1.77 and 1.36 times respectively compared to clinically healthy chickens (Fig. 3).

The cells with $\mathrm{CD}_{4} 5 \mathrm{RA}^{+}$markers had a location, similar to $\mathrm{CD}^{+}{ }^{+}$-lymphocytes, and 40-day-old chickens with the nephroso-nephrite form of AIB had a considerable accumulation of CD45RA ${ }^{+}$-lymphocytes in the interlobular connective tissue (Fig. 2,c). Their amount in sick chickens was reliably higher compared to clinically healthy chickens (Table).

According to the data of the immunohistochemical studies of the harderian gland, 20-day-old chickens with infectious bronchitis had lymphocytes with CD20 $0^{+}$ markers in the interlobular connective tissue. However, 40-day-old chickens with nephroso-nephrite form of AIB had mature B-lymphocytes which were located in the diffuse lymphoid tissue, and formed insignificant accumulations, were present in the cytopopulation of the evolved lymphoid nodules. It is noteworthy that in case of a respiratory form of AIB a considerably higher 

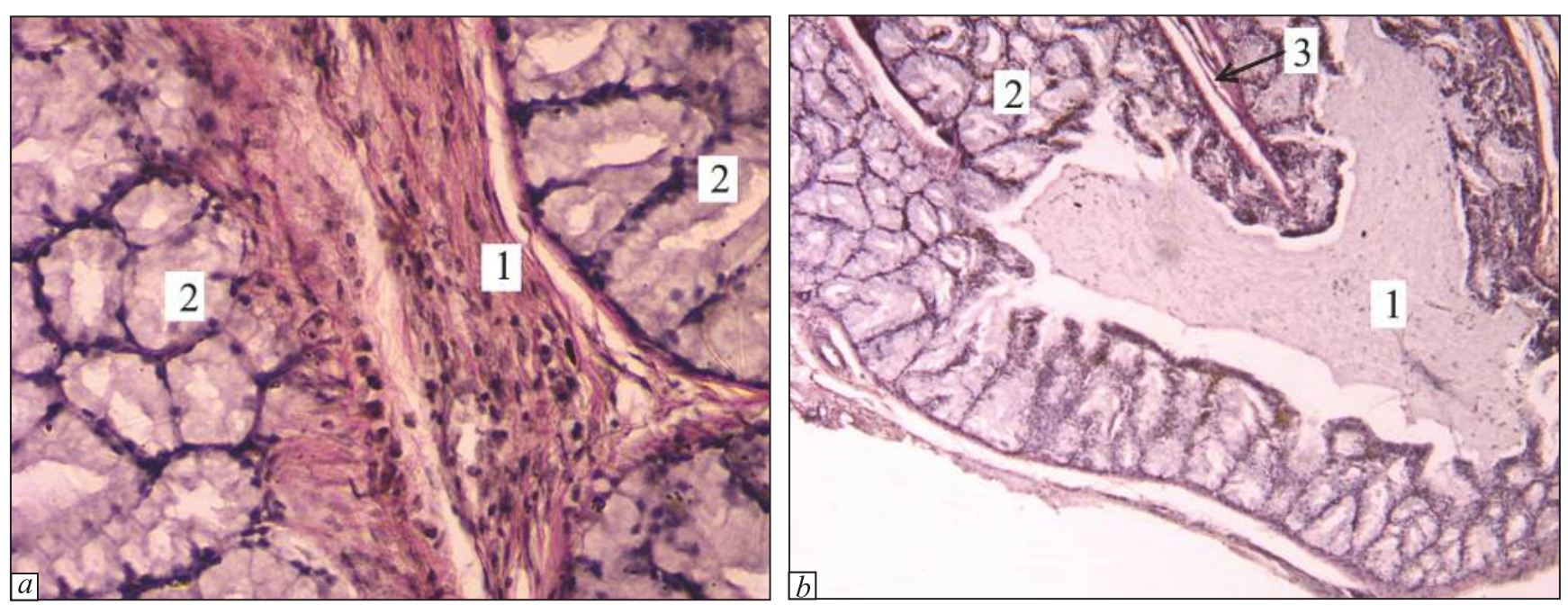

Fig. 1. The microscopic structure of the harderian gland of a chicken with infectious bronchitis. Van Gieson's staining. $a-20$ days old: 1 . swollen interlobular connective tissue and its infiltration by lymphoid cells; 2 . secretory lobule. $\times 400 ; b-90$ days old: 1 - a duct of the secretory lobule; 2 - secretory lobule; 3 - interlobular connective tissue. $\times 100$
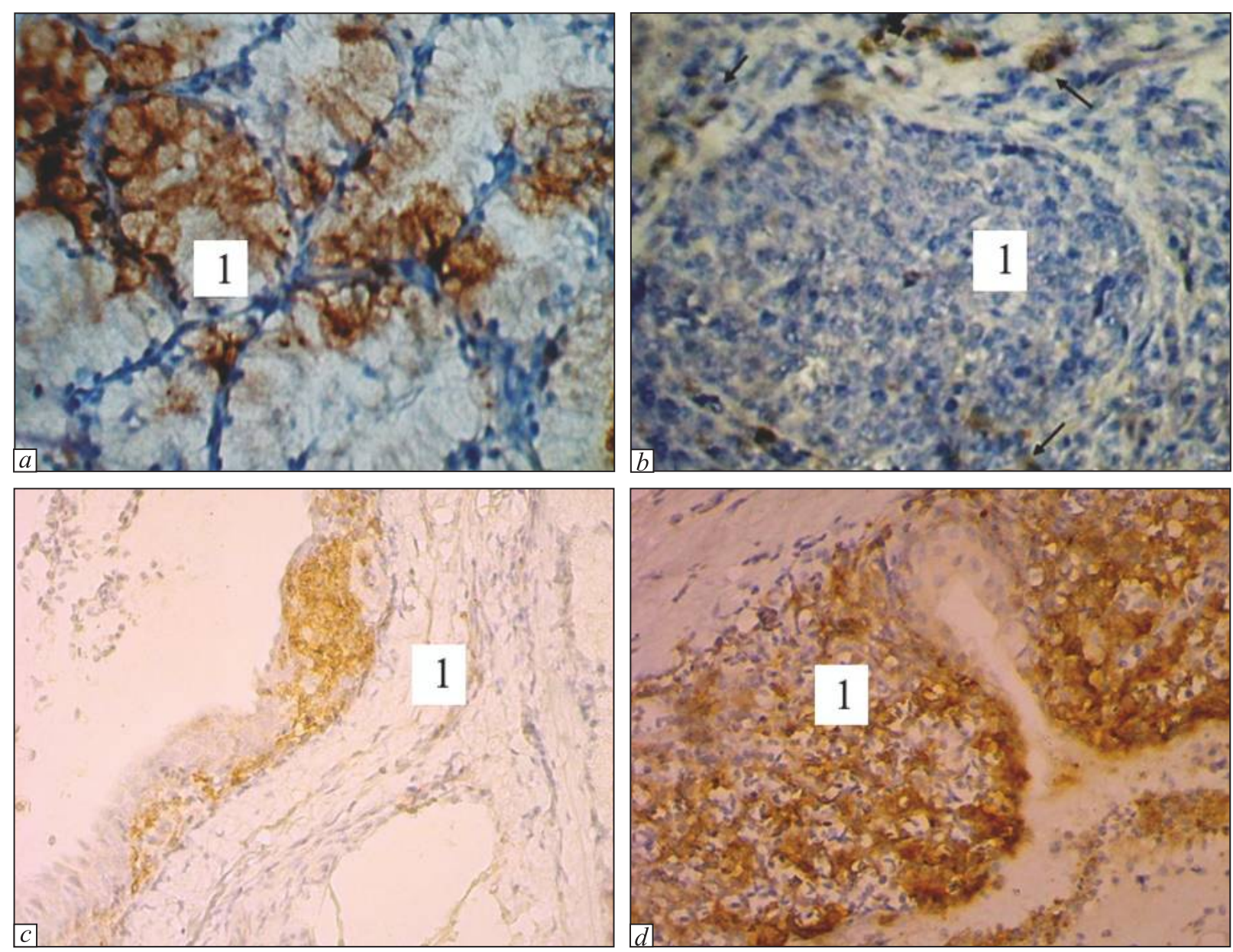

Fig. 2. The histopreparations with monoclonal antibodies, additionally stained with hemalum. $\times 400 a-\mathrm{CD}^{+}-$-lymphocytes in the harderian gland of a 40-day-old chicken with infectious bronchitis: 1 - secretory lobule; $b-\mathrm{CD} 8^{+}$-lymphocytes (arrows) in the harderian gland of a 40-day-old chicken with infectious bronchitis: 1 - lymphoid nodule; $c-\mathrm{CD}_{4} 5 \mathrm{RA}^{+}$-lymphocytes in the harderian gland of a 40-day-old chicken with infectious bronchitis: 1 - interlobular connective tissue; $d$ - CD2 $0^{+}$-lymphocytes in the lymphoid nodules of the harderian gland of 90-day-old chickens with infectious bronchitis: 1 - lymphoid nodules 
amount of these cells was found in the interlobular connective tissue compared to 20-day-old chickens.

In the harderian gland of sick 90-day-old chickens, the lymphocytes with $\mathrm{CD} 20^{+}$markers were localized in the lymphoid nodules (Fig. 2, $d$ ) and took a considerable part of their area. Insignificant amounts of these cells were often noted in the central part of the nodule, where they formed germinal centers.

Cytomorphometric studies demonstrated that the number of subpopulations of lymphocytes with CD20 markers in the harderian gland of sick chickens reliably $(\mathrm{P}<0.05)$ increased compared to clinically healthy chickens: in sick 20-day-old chickens - 2.44 times, 40-day-old ones - 1.88 and sick 90-day-old chickens 2.62 times (Table).

\section{DISCUSSION}

The results of our investigations demonstrated that the most expressed immune responses in the harderian gland of chickens with infectious bronchitis were registered in 40 and 90-day-old chickens.

According to the scientific literature data, avian infectious bronchitis is widely common both globally and domestically, and the outbreaks of this infection cause considerable economic damage for poultry breeding establishments (Alazawy A et al, 2017, Bande F et al, 2017, Habibi $\mathrm{M}$ et al, 2017). According to our observations, 20 and 40-day-old poultry is the most susceptible to AIB, which is in good agreement with the data of other authors (Cook J et al, 2012, Bande F et al, 2015, Bru T et al, 2017). Our data demonstrate that the AIB virus affects chickens up to the age of 90 days which is in good agreement with the data of other authors who stated that up to the age of 30 days chickens mainly had a respiratory form of AIB; 3-9-week-old and older chickens - a nephroso-nephrite form (Cook J et al, 2012, Bande F et al, 2015, Ali A et al, 2018).

The results, obtained by us, confirm and supplement the scientific data stating that the replication of the AIB agent starts in the epithelium of the harderian gland (Bande $\mathrm{F}$ et al, 2015). While studying the harderian gland, infected with AIB virus, Davelaar F, Kouwenhoven B (1976) noted the hyperemia of the lymphoid nodules, degeneration of lymphocytes and plasma cells. In the authors' opinion, it demonstrates that the lymphoid nodules in the harderian gland are involved in the immune response to the AIB virus. The formation of lymphoid nodules was noted 14 days after chickens were infected with the AIB virus, which was not observed in clinically healthy chickens of the same age. The plasma cells were present in single lobules near the central collecting duct of the harderian gland in 20-day-old chickens with AIB. It means that the progressing infiltration of plasma cells in the harderian gland is getting accelerated with age and enhanced by conjunctival and intranasal infection with the AIB virus (Davelaar F, Kouwenhoven B, 1976).

According to our data, the infectious bronchitis virus has immunosuppressive effect on the harderian gland. While investigating the harderian gland, expressed changes were mostly observed in the chickens, which got sick at the age of 40 and 90 days. The vessels of the microcirculatory bloodstream were overfilled with blood, which caused the swelling of the connective tissue. These changes were manifested in the proliferation of the connective tissue, infiltration of secretory lobules

The number of subpopulations of lymphocytes in the harderian gland of clinically healthy chickens and those with infectious bronchitis, birds $(\mathrm{M} \pm \mathrm{m})$

\begin{tabular}{|c|c|c|c|c|}
\hline \multirow{2}{*}{$\begin{array}{l}\text { Groups of chickens } \\
\qquad(\mathrm{n}=6)\end{array}$} & \multicolumn{4}{|c|}{ Indices } \\
\hline & $\mathrm{CD}^{+}$ & $\mathrm{CD}^{+}$ & $\mathrm{CD} 45 \mathrm{RA}^{+}$ & $\mathrm{CD} 20^{+}$ \\
\hline \multicolumn{5}{|c|}{20 days old } \\
\hline $\begin{array}{l}\text { Clinically healthy } \\
\text { Sick }\end{array}$ & $\begin{aligned} & 9.83 \pm 0.49 \\
& 23.17 \pm 1.43 * \\
&\end{aligned}$ & $\begin{array}{c}- \\
34.28 \\
\end{array}$ & $\begin{array}{l}13.78 \pm 0.59 \\
21.38 \pm 1.69^{*}\end{array}$ & $\begin{array}{l}14.61 \pm 0.96 \\
35.72 \pm 1.23 * \\
\end{array}$ \\
\hline \multicolumn{5}{|c|}{40 days old } \\
\hline $\begin{array}{l}\text { Clinically healthy } \\
\text { Sick }\end{array}$ & $\begin{array}{c}11.33 \pm 0.43 \\
31.44 \pm 1.11 *\end{array}$ & $\begin{array}{c}8.38 \pm 0.38 \\
40.56 \pm 0.97 *\end{array}$ & $\begin{array}{l}14.06 \pm 0.59 \\
23.72 \pm 0.92 *\end{array}$ & $\begin{array}{l}27.72 \pm 1.72 \\
52.11 \pm 1.69 *\end{array}$ \\
\hline \multicolumn{5}{|c|}{90 days old } \\
\hline $\begin{array}{l}\text { Clinically healthy } \\
\text { Sick }\end{array}$ & $\begin{array}{c}10.94 \pm 0.48 \\
37.11 \pm 1.16 *\end{array}$ & $\begin{array}{c}9.33 \pm 0.49 \\
42.11 \pm 1.29^{*}\end{array}$ & $\begin{array}{l}15.72 \pm 0.49 \\
31.56 \pm 2.81^{*}\end{array}$ & $\begin{array}{l}24.38 \pm 1.03 \\
63.88 \pm 1.49^{*}\end{array}$ \\
\hline
\end{tabular}

Note. ${ }^{*}-\mathrm{P}<0.05$ regarding clinically healthy chickens. 
by lymphoid cells which could have been caused by the effect of the infectious bronchitis virus and led to the immune inflammation of the harderian gland. These results confirm the data, proving that the functioning and division of lymphoid cells in the harderian gland are very important in the defense against infectious diseases (Guo X et al, 2008).

Our studies on the cytomorphological characteristics of the harderian gland of chickens supplement the data of other authors to some extent (Khan M et al, 2007, Kozlu T et al, 2010, Mobini B, 2012, KleckowskaNawrot $\mathrm{J}$ et al, 2016). For instance, according to the data of Kleckowska-Nawrot J et al (2016), lymphoid cells were observed in the harderian gland partitions and secretory lobules. Numerous plasma cells were noted in the glandular part. According to the study of Khan M et al. (2007), plasma cells of the harderian gland of birds were located in the interstitial space, apical part of the lobules and in the lobules of the organ. At the same time, Kleckowska-Nawrot J et al (2016) observed that plasma cells had a direct contact with epithelial cells and surrounded the ducts tightly. In the researchers' opinion, it means that B-cells of the cloacal sac migrate into the harderian gland via blood circulation. These B-cells are further differentiated into plasma cells and go to the apical parts of the lobules, forming Ig (Khan $\mathrm{M}$ et al, 2007). In the studies, conducted by Mobini B (2012), plasma cells were observed under the capsule, in the interlobular connective tissue trabecules and near the main duct. According to the results of Kozlu T et al (2010), the interlobular connective tissue trabecules of the harderian gland are characterized by a small amount of plasma cells, in the studies of Kleckowska-Nawrot J et al (2016) plasma cells may be localized in the center of the lobules. In our previous studies we observed the enlarged lymphoid tissue in the harderian gland of vaccinated chickens compared to the non-vaccinated ones (Guralska S et al, 2020). Our results confirm the data, stating that lymphoid nodules of the harderian gland are not observed in the chickens up to the age of 40 days (Bejdic P et al, 2014, Guralska S, Budnik T, 2020, Guralska S et al, 2020).

According to the data of our immunohistochemical investigations, single mature B-lymphocytes $\left(\mathrm{CD} 20^{+}\right)$ were found in the interlobular connective tissue of 20-day-old chickens. However, in 40 and 90-day-old chickens B-lymphocytes were found in the interlobular connective tissue, secretory lobules, diffuse lymphoid tissue and in the cytopopulation of the evolved lym-

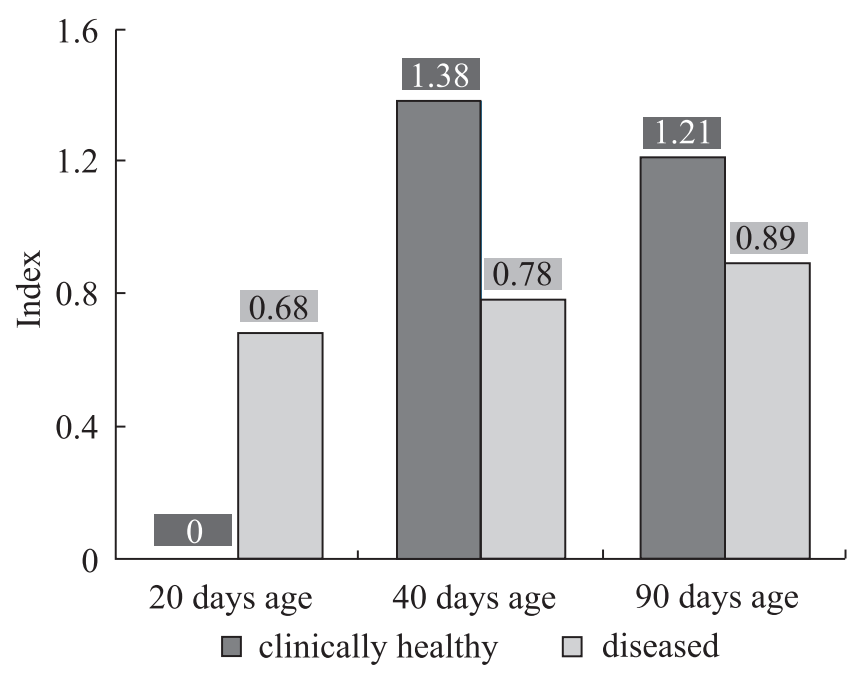

Fig. 3. The differentiation index of the harderian gland cells in clinically healthy chickens and those with infectious bronchitis

phoid nodules. At the same time, a considerable accumulation of naive T-helpers, B-lymphocytes and monocytes with surface markers CD45RA ${ }^{+}$was observed in the interlobular connective tissue and secretory lobules of the harderian gland of 40 and 90-day-old chickens, these cells were not found in the lymphoid nodules.

Proper estimation of the humoral link of the immunity requires the consideration of the level of T-helpers (CD4 $4^{+}$-lymphocytes), as the synthesis of antibodies is a T-dependent process (Gurjar R et al, 2013). T-helpers with surface marker $\mathrm{CD}^{+}$play a central role in the immunity, in maintaining the defense reactions of the organism and ensuring the immune response to infections (Raphael I et al, 2020).

While vaccinating chickens against infectious bronchitis it was determined that cells $\mathrm{CD} 8^{+}$were dominating compared to $\mathrm{CD}^{+}$-lymphocytes (Chhabra $\mathrm{R}$ et al, 2015). Cytotoxic T-cells play an important role in the immune response to the avian infectious bronchitis virus (Gurjar R et al, 2013, Zegpi R et al, 2019). Dai M et al (2019) demonstrate in their articles that T-cells of chickens play a relevant role in fighting a viral infection, ensuring stable and immunocross defense.

It was noted in our previous results of investigations that no lymphocytes with surface markers $\mathrm{CD} 8^{+}$were found in the harderian gland of the vaccinated 20-dayold chickens (Guralska S et al, 2020). However, the results of studying the immunohistochemical indices have proven the presence of T-cytotoxic cells with surface markers $\mathrm{CD}^{+}$in sick 20 -day-old chickens that were not found in clinically healthy chickens of this age (Guralska S, 2017). The impairment in the number 
of the immunoregulatory cells in the harderian gland of sick chickens was observed.

According to the data of Ginkel F et al (2008), the immunosuppressive virus of AIB affects the decrease in the number of $\mathrm{CD}^{+} / \mathrm{CD}^{+}$in the harderian gland which is an indicator of weaker immune response of the mucosa. The decrease in the differentiation index confirms our results, demonstrating that the AIB virus affects the decrease in the ratio of $\mathrm{CD}^{+} / \mathrm{CD}^{+}$lymphocytes (Ginkel F et al, 2008, Chhabra R et al, 2015, Guralska S et al, 2020). In case of a nephrosonephrite form of avian infectious bronchitis, there is also a decrease in the differentiation index, which indicates that the function of defense cells in the organism is weakened, and the regulation on the part of T-cytotoxic cells is excessive.

\section{CONCLUSIONS}

During the immune response to the infectious antigen, including infectious bronchitis coronavirus, there is enhanced production of subpopulations of T-lymphocytes in the harderian gland: T-helper lymphocytes, T-cytotoxic cells with $\mathrm{CD}^{+}$and $\mathrm{CD} 8^{+}$markers in sick 40 and 90-day-old chickens. These cells have a low ratio and a decreased differentiation index compared to healthy poultry (1.77 and 1.36 times respectively) which demonstrates the activation of the immune system of the organism to eliminate the alterative agent which is manifested in the development of immune inflammation in the harderian gland. A considerable proliferation of cells with CD45RA markers was noted: naive T-helpers, B-lymphocytes and monocytes, and their highest activity was observed in 90-day-old chickens when it was 2.01 times higher than this index for healthy poultry, and the number of mature B-lymphocytes with $\mathrm{CD} 20^{+}$markers was 2.62 times higher in 90-day-old chickens compared to similar indices of clinically healthy poultry.

Thus, the study of quantitative and qualitative composition of lymphocytes with $\mathrm{CD}^{+}, \mathrm{CD}^{+}$, $\mathrm{CD}_{45 \mathrm{RA}^{+}}$and $\mathrm{CD} 20^{+}$markers in the harderian gland of chickens with infectious bronchitis supplements the data about cytoarchitecture, development and significance of the harderian gland of chickens in case of this pathology.

Adherence to ethical principles. The investigations were conducted with adherence to General Ethical Principles for Experiments on Animals (Ukraine, 2001), which is in agreement with the Law of Ukraine On Protection of Animals from Cruelty No. 3447-IV dated February 21, 2006 and the provisions of the European Convention for Protection of Animals Used for Experimental and Other Scientific Purposes.

Conflict of interest. The authors do not have any conflict of interests.

Financing. The investigation was conducted with the support of the state fund, grant "Morphology, immunology of coronavirus infections (avian infectious bronchitis, canine coronavirus), their diagnostics and prevention", state registration No. 0118 U003815.

\section{Імунна відповідь гардерової залози курей на коронавірус інфекційного бронхіту \\ С. В. Гуральська ${ }^{1}$, Т. Ф. Кот ${ }^{1}$, Н. В. Дишлюк ${ }^{2}$, С. С. Заїка ${ }^{1}$, 3. В. Хоменко ${ }^{1}$

$$
\begin{gathered}
{ }^{1} \text { Поліський національний університет } \\
\text { Старий бульвар, 7, Житомир, Україна, } 10008 \\
{ }^{2} \text { Національний університе́т біоресу́рсів } \\
\text { і природокористува́ння Украйни, } \\
\text { вул. Героїв Оборони, 15, Київ, Україна, } 03041
\end{gathered}
$$

E-mail: guralska@ukr.net*,tkotvet@ukr.net,dushlyuk@ ukr.net, lana_zaika@ukr.net, zorianakhomenko@ukr.net

Мета. 3'ясувати відмінність імунних реакцій гардерової залози у клінічно здорових курей та за наявності інфекційного бронхіту, на основі вмісту, локалізації та морфометричного обрахунку поверхневих маркерів Т- i В-лімфоцитів, а також визначення індексу диференціації, як показника для оцінки захисних сил організму. Методи. Гістологічні, імуногістохімічні, світлооптичні, морфометричні, статистичні. Результати. За гістологічного дослідження гардерової залози курей при інфекційному бронхіті виявляли набряк сполучної тканини та iï розростання, а також інфільтрацію лімфоїдними клітинами секреторних часточок. З'ясували, що стан імунітету курей за інфекційного бронхіту, в якому важливу роль відіграє гардерова залоза, істотно залежить від індексу диференціації імунокомпетентних клітин. Відмічали вірогідне зниження даного показника у курей 40- та 90добового віку за нефрозо-нефритної форми інфекційного бронхіту у 1,77 та 1,36 рази відповідно, що свідчить про ослаблену функцію захисних клітин органу. Згідно 3 цитоморфометричним аналізом, кількість клітин, які експресують маркери $\mathrm{CD} 4^{+}, \mathrm{CD}^{+}, \mathrm{CD} 20^{+}, \mathrm{CD}_{4} 4 \mathrm{RA}^{+}$у гардеровій залозі хворих курей 20-, 40- та 90-добового віку за респіраторної та нефрозо-нефритної форм інфекційного бронхіту вірогідно $(\mathrm{P}<0,05)$ зростала порівняно з клінічно здоровими курами. Зокрема, зрілі В-лімфоцити зросли у хворих 20-добового віку - у 2,44 рази, 40-добового - у 1,88 раза та у 90 -добового - у 2,62 рази по відношенню до клінічно здорового поголів'я. Висновки. Отримано дані про зміни кількісного i якісного складу лімфоцитів 3 поверхневими маркерами $\mathrm{CD}^{+}, \mathrm{CD}^{+}, \mathrm{CD} 20^{+}, \mathrm{CD}_{45 \mathrm{RA}^{+}}$у гардеровій залозі курей за інфекційного бронхіту. Отримані результати 
дають змогу розширити сучасні знання про доцільність використання імуногістохімічних методів для діагностики інфекційного бронхіту курей.

Ключові слова: В-лімфоцити, гуморальний імунітет, імуносупресія, інфекційний бронхіт курей, наївні Тхелпери, натуральні Т-хелпери, Т-цитотоксичні клітини, чужорідний антиген.

\section{REFERENCES}

Alazawy AKS, Abdulhussain SR, Nasser AT, Albaldawy $A A A$, Bande F., Jameel GH. (2017) Serological survey and molecular detection of infectious bronchitis virus in broiler chickens in Diyala Province. Iraq. Poult. Sci. 16(3):88-92. doi: 10.3923/ijps.2017.88.92.

Ali A, Kilany WH, Zain El-Abideen MA, El Sayed M, Elkady $M$. (2018) Safety and efficacy of attenuated classic and variant 2 infectious bronchitis virus candidate vaccines. Poult. Sci. 97(12):4238-4244. doi: 10.3382/ps/pey312.

Balestrin E, Fraga AP, Ikuta N, Canal CW, Fonseca ASK, Lunge VR. (2014) Infectious bronchitis virus in different avian physiological systems - a field study in Brazilian poultry flocks. Poult. Sci. 93(8):1922-1929. doi: 10.3382/ ps.2014-03875.

Bande F, Arshad SS, Bejo MH, Moeini H, Omar AR. (2015) Progress and challenges toward the development of vaccines against avian infectious bronchitis. J. Immunol. Res. doi: 10.1155/2015/424860.

Bande F, Arshad SS, Omar AR, Hair-Bejo M, Nair V. (2017) Global distributions and strain diversity of avian infectious bronchitis virus: a review. Anim. Health. Res. Rev. 18(1):70-83. doi: 10.1017/S1466252317000044.

Bejdic $P$, Avdic R, Amidzic L, Cutahija $V$, Tandir F, Hadziomerovic N. (2014) Developmental changes of lymphoid tissue in the harderian gland of laying hens. Mac. Vet. Rev. 37(1):83-88. doi: 10.14432/j. macvetrev.2014.02.009.

Bru T, Vila R, Cabana M, Geerligs HJ. (2017) Protection of chickens vaccinated with combinations of commercial live infectious bronchitis vaccines containing Massachusetts, Dutch, and QX-like serotypes against challenge with virulent infectious bronchitis viruses $793 \mathrm{~B}$ and IS/1494/06 Israel variant 2. Avian. Pathol. 46(1):52-58. doi: 10.1080/03079457.2016.1203393.

Cavanagh D. (2007) Coronavirus avian infectious bronchitis virus. Vet. Res. 38(2):281-297. doi: 10.1051/vetres:2006055.

Chhabra R, Forrester A, Lemiere S. (2015) Mucosal, Cellular, and Humoral Immune Responses Induced by Different Live Infectious Bronchitis Virus Vaccination Regimes and Protection Conferred against Infectious Bronchitis Virus Q1 Strain. Clinic. Immunol. 22(9):1050-1059. doi: 10.1128/CVI.00368-15.

Cook JKA, Jackwood M, Jones RC. (2012) The long view: 40 years of infectious bronchitis research. Avian. Pathol. 41:239-250. doi: 10.1080/03079457.2012.680432.

Dai M, Xu C, Chen W, Liao M. (2019) Progress on chicken
T cell immunity to viruses. Cell Mol. Life Sci. 76(14): 2779-2788. doi: 10.1007/s00018-019-03117-1.

Davelaar FG, Kouwenhoven B. (1976) Changes in the harderian gland of the chicken following conjunctival and intranasal infection with infectious bronchitis virus in one- and 20-day-old chickens. Avian. Pathol. 5(1):3950. doi: 10.1080/03079457608418168.

Dhinakar Raj G, Jones RC. (1997) Infectious bronchitis virus: Immunopathogenesis of infection in the chicken. Avian. Pathol. 26(4):677-706. doi: 10.1080/ 03079459708419246.

Frahmand S, Mohammadpour AA. (2015) Harderian gland in Canadian ostrich (Struthio camelus): A morphological and histochemical study. Anat. Hist. Embryol. 44(3):178-185. doi: 10.1111/ahe.12123.

Ginkel FW, Santen VL, Gulley SL, Toro H. (2008) Infectious bronchitis virus in the chicken harderian gland and lachrymal fluid: viral load, infectivity, immune cell responses, and effects of viral immunodeficiency. Avian. Dis. 52(4):608-617. doi: 10.1637/8349-050908-Reg.1.

Guo X, Rosa A J, Chen DG, Wang X. (2008) Molecular mechanisms of primary and secondary mucosal immunity using avian infectious bronchitis virus as a model system. Vet. Immunol. Immunopathol. 121(3-4):332-343. doi: 10.1016/j.vetimm.2007.09.016.

Guralska S. (2017) Immunohistochemistry of the organs of hemopoiesis and immunogenesis of chickens at infectious bronchitis. Vet. Biotech. 31:50-58. doi: 10.31073/vet biotech31-06.

Guralska S, Budnik T (2020) The morphology of the chicken's harderian gland for vaccination and application of Avesstim ${ }^{\mathrm{tm}}$. Sci Horizons 1 (86):79-88. doi: 10.33249/2663-2144-2020-86-1-79-88

Guralska S, Kot T, Pinskyi O, Sokolyuk V, Budnik T. (2020) Morphofunctional condition of the harderian gland of chickens during the post-vaccine immunity to infectious bronchitis. Agric. Sci. Pract. 7(1):32-39. doi: 10.15407/ agrisp7.01.032.

Guralska S, Kot T, Zaika S, Sokulskii I, Khomenko Z. (2019) Pathomorphology of chicken organs with respiratory, nephroso-nephritic and reproductive form of infectious bronchitis. Sci. Horizons. 8(81):3-12. doi: 10.33249/2663-2144-2019-81-8-3-12.

Gurjar RS, Gulley SL, Ginkel FW. (2013) Cell-mediated immune responses in the head-associated lymphoid tissues induced to a live attenuated avian coronavirus vaccine. Dev. Comp. Immunol. 41(4):715-722. doi: 10. 1016/j.dci.2013.08.002.

Habibi M, Karimi V, Langeroudi AG, Ghafouri SA, Hashemzadeh M, Farahani RK, Maghsoudloo H, Abdollahi $H$, Abdollahi P. (2017) Combination of $\mathrm{H} 120$ and $1 / 96$ avian infectious bronchitis virus vaccine strains protect chickens against challenge with IS/1494/06 (variant 2) -like infectious bronchitis virus. Acta Virol. 61(2):150-160. doi: 10.4149/av_2017_02_04. 
GURALSKA et al.

Ignjatovic J, Sapats S. (2000) Avian infectious bronchitis virus. Rev. Sci. Tech. 19(2):493-508. doi: 10.20506/ rst.19.2.1228.

Jackwood MW. (2012) Review of infectious bronchitis virus around the world. Avian. Dis. 56(4):634-641. doi: 10.1637/10227-043012-Review.1.

Jahan MR, Islam MN, Khan MZI, Yanai A. (2018) Morphometry and expression of immunoglobulins-conaining plasma cells in the harderian gland of birds. J. Adv. Biotechnol. Exp. Ther. 1(2):55-60. doi: 10.5455/ jabet.2018.d10.

Jahan MR, Khan MZI, Islam MN, Akter SH. (2006) Morphometrical analysis of harderian gland of broiler and native chickens of Bangladesh. J. Bangladesh. Agric. Univ. 4(2):273-278. https://doi.org/10.22004/ ag.econ. 276555 .

Karimi V, Mohammadi P, Ghalyanchilangeroudi A, Ghafouri SA, Hashemzadeh M, Farahani RK, Maghsouldoo H, Isakakroudi N. (2019) Including 793/B type avian infectious bronchitis vaccine in 1-day-old chicken increased the protection against QX genotype. Trop. Anim. Health Prod. 51(3):629-635. doi: 10.1007/s11250-0181730-4.

Khadija K, Siham F, Chafiqa L, Ennaji MM. (2016) Avian infectious bronchitis virus in Africa: a review. Vet Q. 36(2):71-75. doi: 10.1080/01652176.2015.1126869.

Khan M ZI, Jahan MR, Islam MN, Haque Z, Islam MR, Kon $Y$. (2007) Immunoglobulin (Ig)-containing plasma cells in the harderian gland in broiler and native chickens of Bangladesh. Tissue Cell. 39(3):141-149. doi: 10.1016/j. tice.2007.02.005.

Kleckowska-Nawrot J, Gozdziewska-Harlajczuk K, Barszcz $K$, Kowalczyk A. (2015) Morphological studies on the harderian gland in the ostrich (Struthio camelus domesticus) on the embryonic and post-natal period. Anat. Hist. Embryol. 44(2):146-156. doi: 10.1111/ahe.12124.

Kleckowska-Nawrot J, Gozdziewska-Harlajczuk K, Kowalczyk A, Lukaszewicz E, Nowaczyk R. (2016) Structural
Differences of the Harderian Gland between Common Pheasants (Phasianus Colchicus Talischensis) and Hybrids of Italian Amber and Common Pheasants. Braz. J. Poul. Sci. 18(2):309-318. doi: 10.1590/1806-90612015-0059.

Kozlu T, Bozkurt YA, Altunay H, Sari EK. (2010) Histological and histochemical studies on the harderian gland of the osprey (Pandion haliaetus). J. Anim. Vet. Adv. 9(13):1875-1879. doi: 10.3923/javaa.2010.1875.1879.

Mobini B. (2012) Histological and histochemical studies on the harderian gland in native chickens. Vet. Med. 57(8):404-409. doi: 10.17221/6308-VETMED.

Najimudeen SM, Hassan MSH, Cork SC, Abdul-Careem $M F$. (2020) Infectious Bronchitis Coronavirus Infection in Chickens: Multiple System Disease with Immune Suppression. Pathogens. 9(10):779. doi: 10.3390/pathogens9100779.

Raphael I, Joern RR, Forsthuber TG. (2020) Memory CD4+ $\mathrm{T}$ Cells in Immunity and Autoimmune Diseases. Cells. 9(3):531. doi: 10.3390/cells9030531.

Sarah EA, Helmy AT, Seddeek ME. (2014) Antigenic variations of infectious bronchitis virus from broiler flocks in Al Behera Governorate. AJVS. 40:44-51. doi: 10.5455/ajvs.46652.

Smith J, Sadeyen JR, Cavanagh D, Kaiser P, Brut DW. (2015) The early immune response to infection of chickens with Infectious Bronchitis Virus (IBV) in susceptible and resistant birds. BMC Vet. Res. 11(1):256. doi: 10.1186/ s12917-015-0575-6.

Valastro V, Holmes EC, Britton P, Fusaro A, Jackwood MW, Cattoli G, Monne I. (2016) S1 gene-based phylogeny of infectious bronchitis virus: an attempt to harmonize virus classification. Infect. Genet. Evol. 39:349-364. doi: 10.1016/j.meegid.2016.02.015.

Zegpi RA, Breedlove C, Gulley S, Toro H. (2019) Infectious Bronchitis Virus Immune Responses in the Harderian Gland upon Initial Vaccination. Avian. Dis. 64(1):92-95: doi: 10.1637/0005-2086-64.1.92. 